\title{
Stance, Style, and the Linguistic Individual
}

\author{
Barbara Johnstone \\ Department of English \\ Carnegie Mellon University \\ Pittsburgh PA 15213, USA \\ bj4@andrew.cmu.edu
}

\section{OVERVIEW}

Repeatable linguistic styles emerge out of stancetaking strategies that prove repeatedly relevant and useful for particular speakers in particular kinds of interactions. Previous research has explored how styles can come to be associated with interactional situations (e.g. Biber and Finegan 1989) or social identities (eg. Ochs 1992, Eckert 2000). In some sociocultural contexts, styles associated with individuals can also become ethnographically and interactionally relevant, although we have paid less attention to these. This paper uses a discourse-analytic case study of one individual's talk and writing across genres, together with ethnographic, biographical, and historical research about the sociolinguistic and language-ideological contexts, to illustrate how repeated patterns of stancetaking can come together as a style associated with a particular individual. The individual in question, a well-known 20th-century U.S. political figure, was known for how she talked, which was sometimes referred to as "the Barbara Jordan style." As I will show, Jordan drew on discursive resources from the African-American church and from the American traditions of legal and political debate and oratory, as mediated by particular people in her environment, to create a linguistic style that she adopted across discourse genres. In keeping with one of the two the dominant Western ideologies about the role of identity in persuasion, this style worked rhetorically by 
constructing and calling attention to moral and epistemological authority stemming from consistent personal identity rather than changeable social identity. I refer to this rhetorical strategy as the ETHOS OF SELF.

I begin by sketching the models of stancetaking and style I draw on, summarizing corpuslinguistic, anthropological, and sociolinguistic research that shows how repeatable styles emerge in the course of repeated stancetaking choices. I then turn to my case study. After introducing Barbara Jordan, I claim that for reasons having to do with local beliefs about identity and discourse, Jordan's style needed, in her sociocultural environment, to be recognizeably associated not just with one or more social identities such as being female, black, an attorney, or a politician, but with a unique, consistent personal identity linked to a unique life history: with being Barbara Jordan. I provide four kinds of evidence for this claim:

- First, using historical evidence, I show that the classical rhetorical idea that persuasion is sometimes effected through the projection of individual personal identity into discourse continues to circulate in the American languageideological context. I describe the rhetorical strategy associated with this idea, which, using a traditional rhetorical term, I call the ethos of self: the discursive enactment of epistemic and moral authority linked to a unique "lingual biography" (Johnstone 1999).

- Second, using biographical evidence, I show that the idea of the ethos of self as a valued rhetorical strategy was present in Jordan's particular sociolinguistic 
environment, and that some of the linguistic resources for enacting it may have been drawn from discursive registers that came together in Jordan's life history.

- Third, using textual evidence, I show how "the Barbara Jordan style" emerges out of interactional and epistemic stancetaking moves that project personal epistemic and moral authority: informational, fairly non-interactive talk, full of markers of certainty, together with explicit references to Jordan's own life experience. I also suggest that, in this language-ideological context, cross-genre consistency itself works to project authority.

- Fourth, I turn more briefly to evidence about how Jordan's style is identified and understood by people who heard her speaking, suggesting that it is at least in part Jordan's use of the ethos of self that makes her seem so "powerful" to others.

Finally, I speculate about the reasons for sociolinguistics' silence about how stance can be organized into style on the level of the individual, and I suggest what we have to gain by taking individual style more seriously.

\section{THEORETICAL FRAMEWORK}

\section{What is stance?}

Stance is generally understood to have to do with the methods, linguistic and other, by which interactants create and signal relationships with the propositions they utter and with the people they interact with. Early work (Biber and Finegan 1989) focused on evidentiality and affect, examining textual features that can signal the source of speakers' knowledge and their degree of certainty, as well as their attitudes about the propositions they utter. In more recent work taking a similar approach, Hunston and Thompson 
(2000) explore the linguistics of "evaluation." For them, "evaluation is the broad cover term for the expression of the speaker or writer's attitude or stance towards, viewpoint on, or feelings about the entities or propositions that he or she is talking about. That attitude may related to certainty or obligation or desirability or any of a number of other sets of values." (5) According to Hunston and Thompson, evaluation has three functions (6-13): expressing the opinion of the speaker/writer vis à vis the propositions being expressed, manipulating the hearer/reader's attitude vis à vis these propositions (in part by constructing and maintaining relationships between speaker/writer and hearer/reader), and organizing the discourse, for example, by marking boundaries or highlighting significant parts Because evaluating a proposition often involves comparing it against a norm, linguistic features associated with evaluation may include such things as comparative adjectives, negation, and adverbs of degree. The language of evaluation may also involve markers of subjectivity such as modals, sentence adverbs and conjunctions and structures that report and attribute speech, as well as markers of value, such as lexical items that are evaluative and indications of whether goals are achieved $(21-22){ }^{1}$

Since taking a particular attitude towards propositions - such as uncertainty - may index a particular social relationship or attribute - such as powerlessness -- stancetaking inevitably has to do with both epistemic and interactional aspects of perspective-taking in discourse. Goffman's (1981) "footing" includes elements of both, though it highlights the interactional, as does Hunston and Thompson's second function of "evaluation" having to do with the ways in which interlocutors try to manipulate each other's attitudes 
vis à vis the propositions being expressed. Taking a more explicitly sociolinguistic approach, Ochs (1992) models how particular linguistic forms can index evidential stances such as certainty, interpersonal stances such as friendliness or intensity, or social actions such as apologizing. DuBois (forthcoming) takes a similarly broad approach: "stance is a public act by a social actor, achieved through overt means, of evaluating an object, positioning the self, and aligning with other subjects with respect to any salient dimension of the stance field"; the "stance field" consists of two social actors and an object to which both are oriented. Since alignment or disalignment with another social actor could be accomplished through membership categorization moves, social identity claims and ascriptions also fall under the rubric of stancetaking.

Stance and style

Repeated sets of stancetaking moves can emerge as relatively stabilized repertoires, sometimes called "styles," associated with or situations or social identities (Bauman 2004). Styles are (at least to some extent) repeatable. That is to say that sets of stancetaking moves serving a common function are not always assembled de novo in each new situation. As they produce or interpret talk, people can often draw on alreadymade generalizations about the stance features that instantiate a particular style. Styles are often identifiable, by analysts and/or by participants; some have names. Styles associated with a particular set of contextual factors that confront a speaker with a particular set of rhetorical exigencies are sometimes called "registers" (Biber and Finegan 1994, Finegan and Biber 2001). ${ }^{2}$ Sets of stance-taking choices associated with participant roles or subject positions are sometimes referred to under the rubric of 
"footing" (Goffman 1981) or "framing" (Tannen 1979, 1993) . A set of stance-taking choices associated with a socio-demographic identity category is sometimes referred to as a "dialect" or a "variety" and may have a popular designation like "wogspeak" (Kiesling 2005) or "Pittsburghese" (Johnstone \& Baumgardt 2004).

Biber and Finegan's (1989) pioneering work on stance and style identified statistical clusters of co-ocurring stance markers and interpreted these clusters with relation to functional demands created by situation and participation structure. More recent work models how particular clusters of features come to serve particular functions. For Irvine (2004), styles emerge when particular patterns of differentiation become ideologically linked with local, ethnographically relevant social meanings. For example, in a particular sociocultural milieu, stance features that repeatedly proved useful in constructing linguistic deference might become indexically linked with femaleness (Ochs 1992). This happens because of the potential indexicality of all language use: forms that regularly occur in a certain context can come to call up that context.

Eckert's $(1989,2000)$ work in a Detroit high school links stancetaking to social identity via styles. For Eckert, adopting certain variants of vowels is one way adolescents take a stance vis à vis local life, just as is cruising in cars (or not), dressing in a particular way, choosing among school activities. Such activities on all levels can become styles linked with social identities like "jock" or "burnout." Kiesling $(2004,2005)$ goes a step further, attaching labels to the sets of stancetaking choices that index social identites, so as to suggest why a particular style of stance comes to index a particular social identity. In a 
study of recent immigrants in Australia, Kiesling (2005) shows that a particular set of morpho-phonological features which coocur in the migrants' English work together to project a face-saving epistemic and interactional stance Kiesling calls "authoritative connection." This stance, Kiesling claims, is particularly likely to be relevant for members of subordinate groups. Because they work together as a stancetaking strategy, the features get used repeatedly together, and a repeatable style (locally called "wogspeak") emerges, ideologically linked with a repeatable social identity, that of the recent immigrant.

In much of this work, the object of study is language use across idealized groups of speakers. Whether the focus is primarily on language (as for Biber and Finegan, Hunston and Thompson, and others), on social life (as for Goffman, Tannen, Ochs, and others), or on the relationship between the two (as for Eckert, Kiesling, and others), the styles that are described characterize registers, particpant roles, or social identities. Individual social actors enter the picture, if they do at all, to exemplify a style associated with a genre of texts, a discourse activity, an interactional role, or a social group.

Here I redirect attention to locus of style that Western rhetoricians and literary critics have been exploring for centuries: the individual human being. In certain languageideological contexts, stylistic differentiation can be semiotically linked with particular speakers, such that individuals claim to recognize other individuals on the strength of their characteristic ways of using language, and some individuals' linguistic styles may come to be named and emulated. Some of the material I will use to illustrate this is 
drawn from earlier work about Barbara Jordan (Johnstone 1996, 128-155). I supplement it here with new observations about the discourse data assembled earlier, as well as new biographical and critical material about Jordan, of which a great deal has appeared since her death in 1996. The theoretical framework I have developed here is considerably refined from the 1996 version. It provides a clearer picture, I hope, of the interactional and ideological processes that can make the "linguistic individual" (Johnstone 1996, 2000) important, and the reminder that ways of speaking associated with individual language-users may be ethnographically and interactionally relevant fills a gap in the study of stancetaking.

\section{"THE BARBARA JORDAN STYLE"}

\section{Who was Barbara Jordan?}

Barbara Jordan, born in 1936, grew up in Houston, Texas, where she attended all-Black Texas Southern University. She returned to Houston and briefly practiced law there after graduating from law school in Boston. ${ }^{3}$ Then she went into politics. The first AfricanAmerican woman elected to the Texas Senate and subsequently the first AfricanAmerican woman from the South in the U.S. House of Representatives, Jordan rose to prominence through astute politics conducted in part via public oratory which audiences found inspiring. She first gained wide national attention as a result of her televised speech in 1972 as a member of the Judiciary Committee of the House of Representatives, which was deliberating whether President Richard Nixon should be impeached. In 1976 and again in 1992, Jordan gave keynote addresses at the Democratic Party's national convention. Her speeches are widely quoted. Until her death in 1996, she was frequently 
interviewed for print and broadcast, and after her retirement from politics she was a popular teacher at the University of Texas. She is seen as a model for AfricanAmericans, for women, and for politicians, and as an authority on governmental ethics.

\section{Identity And Discourse in the Western Rhetorical Tradition}

I turn now to an exploration of how style can instantiate mainstream U.S. ideology about the role of the individual in discourse. In the classical Greco-Roman rhetorical tradition, the source of Barbara Jordan's training in legal and political debate and oratory, the speaker's "ethos" is seen as a fundamental tool in persuasion. As early students and teachers of oratory observed, a speaker's reputation or social position could enhance his (or her, though women could not speak in public in $5^{\text {th }}$-century BCE Athens) credibility. Ethos, broadly defined, is the speaker's identity as it is constructed and/or deployed in discourse (Baumlin 1994, Cherry 1998). In the Western tradition of rhetoric, ethos is the name for one of the three pisteis or basic modes of persuasive appeal. (The others are logos, or logical appeals to characteristics of the topic, and pathos, or appeals to characteristics of the audience.)

Barbara Jordan's style of stance instantiates one of the two primary ways this ideological tradition provides for imagining the relationship between identity and discourse, and, accordingly, for imagining how rhetorical ethos works. ${ }^{4,5}$ From Platonic idealism comes the conception of ethos as the externalization of a good soul. The character a rhetor displays in discourse is understood as "central" rather than "social" (Baumlin, 1994); discourse is credible if the speaker is (and shows that he or she is) a person with pre- 
existing moral and epistemic authority. Thus the effective rhetor is a "good man skilled in speaking," in Quintilian's well-known formulation. In this tradition, the speaker's character is understood as pre-existing discourse rather than being constructed in it. This is an ethos of self: the projection of knowledge and moral authority derived from one's life history, a history that is necessarily unique because no two individuals' experiences and memories are identical. The Platonic idea that knowledge and morality become evident in introspection - from self - underlies American "expressive individualism" (Bellah, et al. 1985; Hansen 1990).

In Aristotle's pragmatic rhetoric, on the other hand, effective discourse means speaking in such a way as to seem credible, and personas can be adopted more or less like dramatic roles. This could be called the ethos of persona, or the projection into discourse of social roles or less sedimented sets of social expectations. In this view, credibility is linked with skill in adapting to the situation at hand. This way of imagining rhetorical and linguistic agency looks at identity and discourse from the perspective of culture rather than taking the phenomenological perspective of the individual, focusing on sets of expectations about how individuals interact with other individuals in larger systems and describing individuals in terms of shifting sets of social identities.

While popular language ideology in the U.S. continues to be shaped significantly by the Platonic model of ethos, the ethos of self, current scholarly discourse has moved to accounting for human behavior with reference to personhood rather than selfhood, describing individuals in terms of roles and adaptations to situation (e.g., Rosaldo 1984) and replacing the idea of "self-expression" with that of "self-fashioning" (e.g. Greenblatt 
1980). ${ }^{6}$ In this view, knowledge and moral authority arise when certain social processes are followed. One such process might be rational argumentation; alternatively, individuals in certain social positions might be the source of knowledge and moral judgment.

Each of these modes of ethos can be enacted in an individual's characteristic stancetaking choices. An ethos of persona would require inconsistency, the ability to construct different identities to meet different rhetorical exigencies, and to flag this ability by means of metadiscursive and nondiscursive signals of strategic flexibility. Speakers' ability to shift styles and identities in response to audience or situation, constructing interactionally responsive, changing identities in the rhetorical moment, has been the focus of an enormous amount of recent sociolinguistic and anthropological scholarship, much of which draws on Goffman's (1959) important observations about "the presentation of self."

Barbara Jordan's characteristic style of stance works to construct rhetorical ethos rooted not in persona, however, but in self. In other words, her style draws on and helps to construct a world in which the source of morality and knowledge is not social agreement in the moment but lessons learned in the course of thoughtful reflection on one's necessarily idiosyncratic, unique personal biography. Assent, accordingly, is reached not through performances of (flexible) social identity and openness to epistemic and moral negotiation, but through performances of personal identity and epistemic and moral certainty. This requires stance-taking choices that project consistent personal identity 
rather than transient social identity. Among these are, as I will show below, noninteractivity, markers of moral and epistemic authority, consistency across genres, as well as overt references to personal biography.

\section{Ideological and linguistic resources for Jordan's style}

In our interview, we asked Barbara Jordan to talk about the sources of her speech style. She described several, which are corroborated in biographical accounts by others (Bryant 1977, Haskins 1977, Jordan and Hearon 1979, Crawford and Ragsdale 1992: 321-331, Rogers 1998). Jordan's linguistic and language-ideological environment in childhood exposed her to several different sets of ideas about language and multiple models for speech. At home, Jordan's mother encouraged careful, articulate speech ("My mother wanted us to use correct English, and she really never engaged in uh baby talk or Black talk or whatever...”) Jordan grew up attending a Baptist Church where her father was a minister and her mother occupied public-speaking roles that were open to women ("[T]he women would speak at their ... missionary circles ..., but women were not ... encouraged to deliver any sermons ... because that was anathema to the Black Missionary Baptist Church.”) But although Jordan acknowleged the existence of gendered speaking roles, she claimed not to have been expected to speak differently from boys herself. ${ }^{7}$ Jordan's tendency not to style-switch, her care in word choice, and her adherence to the norms of standard, writerly syntax, might all be traced to the standard language ideology (Milroy and Milroy 1985, Cameron 1995, Lippi-Green 1997: 53-62) that underlay her mother's insistence on "correct English", and the linguistic resources for doing this, as well as Jordan's choice of a profession that would require speaking in 
public, may have been facilitated by her mother's model. Jordan's powerful baritone speaking voice might be linked in part to her resistance of gendered speaking roles, as well as in part to biological inheritance. ${ }^{8}$

Research on African-American oratory and homiletics (Abrahams 1972, Pitts 1989, Wharry 2003) points to its roots in the "man of words" tradition of preaching and its interactive qualities in comparison with European-American preaching style. While sociolinguistic research tends to highlight the generic qualities of preaching style, some African Americans appear to link its effectiveness with the ethos of self. In interviews with middle-class African Americans (like Jordan), Speicher and McMahon (1992) found that for some, "the greatness of an [African American] orator lies in each speaker's individual style and distinctiveness," while others pointed to "a combination of individual ability and black oral tradition" (393). Aspects of Jordan's style such as the response-like register-shifted codas we will encounter below, along with aspects of her delivery, might be traced to her minister father's oratorical model and that of other preachers she heard in her youth. Jordan spoke directly to this source of influence, although without claiming it for herself, in our conversation with her (I discuss the stylistic details of this extract later on):

\section{(1) Jordan interview}

JORDAN: You are going to find that there are any number of people who are public speakers who try to reflect what they have heard from their minister, and the black minister has a definable and totally uh in my opinion different style of 
oratory than anybody else in the country. And it is because of that role of the black minister, a role which I don't believe is paramount in any other race or group of people, but it is that, it is there, it is there for us and it is because of that preaching that uh influences I think the way that a person who is black would deliver an an address or a speech

However, as Jordan narrated her lingual autobiography in our interview with her, she repeatedly pointed to her high-school and college experiences in competitive public speaking as the key influences on her understanding and practice of public speaking. Here, for example, she deflects a question about childhood with an answer about high school oratorical contests. ${ }^{9}$

\section{(2) Jordan interview}

BARBARA JOHNSTONE: ... When you were growing up, were you encouraged to talk a lot, or was the rule that children should be seen and not heard?

BARBARA JORDAN: Well I, I did uh always talk a lot, but in uh junior and senior high school of course I was always participating in the various interscholas- interscholastic leagues, the declamation contests, and uh I was on the debate team at uh my, high school Phyllis Wheatley and, at TSU [[Texas Southern University]] and I think that those experiences, of participating in the contests because I always wanted to win the contests, and uh oratorical contests, and, that is where I started to talk publicly ... 
Competitive public speaking, tracing its ideological lineage to the Ciceronean "good man speaking well," helped to shape Jordan's appeal to the ethos of self. It may have provided fuel for the idea that speaking style can be learned and practiced, and it no doubt helped shape her delivery in many ways. Competitive debate and oratory is an element of the lingual biography of many U.S. politicians, but may have been especially important in Jordan's because of the presence of a particular extremely successful and influential high school debate coach, Thomas F. Freeman. ${ }^{10}$ Jordan spoke specificially about how Freeman encouraged "dramatic" delivery:

\section{(3) Jordan interview}

JORDAN: When I was a member of the uh debating team at uh Texas southern us Thomas Freeman who is still the debate coach at Texas Southern uh used to, really insist that we be uh dramatic in our presentation of material, because he was and is so dramatic in his presentation of material. I, and that was an ifluence which he uh put in place on everyone who came his way.

Freeman also encouraged Jordan to attend to the details of elocution, urging her to abandon a hypercorrect form (the use of /hw/ in a word which, for most speakers who use /hw/ at all, is not in the class of words that require it):

(4) Jordan interview 
JORDAN: One thing that I recall Freeman saying to me is that I had a tendency to say "hwe" [hwi] rather than "we," and that's the only thing that I remember that he ever corrected me on, and so he just made me repeat "we, we" so that I and I never would dare say "hwe" even right now.

Finally, Jordan talked about her legal training as a source of her style of speech. Law school, she said, taught her that she could "no longer orate and let that pass for reasoning" (Jordan and Hearon 1979: 93).

\section{(5) Jordan interview}

BARBARA JOHNSTONE: I think [[in]] the the autobiographical book we read that you learned to speak differently in law school in the sense that uh you had to know what you were talking about more ... I'm curious [about that.]

BARBARA JORDAN: [Oh but] I didn't learn to speak differently, I hope that's not in the autobiography because it's incorrect if it is.

JOHNSTONE: Well,=

JORDAN: =I did not learn to speak differently, I learned to think, in law school, that was the difference. I coul- I, I stopped, I stopped writing from the surface of my mind and decided to go inside and see if there was really something there because it was important, to get to the bottom of an idea and be able to uh uh make it hold up in uh legalese, in legal argument. That was important. 
Among the ideas Jordan adduces here which may have shaped her style, are the idea that reasoning precedes writing, the idea that more significant ideas are located deeper in the mind, the idea that one could talk without there being "anything there." Legal training, the need to "make it hold up in legalese, in legal argument" might have added to Jordan's rhetorical repertoire the idea that logos, the appeal to reason, should be valued along with ethos and the pathos of dramatic delivery.

This exploration of the sources of Jordan's ideas about public speech, and the resources for deploying and recycling them, underscores how linguistic ideology, and the discursive resources for its construction and circulation, come together in different complex ways in the lingual biographies of different individuals. It also provides biographical evidence that the ideology associated with the ethos of self was specifically circulating in Jordan's sociolinguistic environment. I turn now to the textual evidence. Through a detailed examination of aspects of Jordan's speech related to stancetaking in particular, I show how they both instantiate and recycle the particular set of ideas about discourse and the individual associated with the ethos of self.

\section{Style emerging in discourse: Authoritative stance in the Jordan corpus}

To explore stance and style in Jordan's speech, I draw on a corpus of 11,967 words drawn from six transcripts that represent the range from Jordan's most public, formal speeches to relatively relaxed, unedited interview speech. Together with Delma McLeod-Porter and Judith Mattson Bean, I conducted the unedited interview in Jordan's University of Texas office in February, 1992. For this analysis, I use three excerpts from 
it, totalling 2,237 words in all. One is from the beginning of the interview, one is from the middle (pages 9 and 10 of the 21-page transcript), and one is from the end. On the other end of the spectrum are published transcripts of Jordan's formal public oratory: excerpts from her House Judiciary Committee speech about the Nixon impeachment (Fernea and Duncan, 1977, pp. 28-32; 1,415 words) and her Democratic Convention keynote speech of 1976 (Braden, 1977, pp. 11-17; 1,804 words). These represent speech with a different purpose and audience (national TV in both cases). The settings were also less intimate, and Jordan had time in both cases to plan, edit, and revise what she was going to say. To check that the printed transcripts corresponded to what Jordan actually said, I audited both speeches on videotape. In the middle of the spontaneous-to-planned continuum, I examined three published interviews with Jordan, two conducted by journalists and one by a professor. One of these short interviews appeared in a collection of conversations with prominent people published at the time of the U.S. Bicentennial (Murchland, 1987, pp. 39-49; Jordan's speech totals 2,818 words), one was an interview in the news weekly Time (Angelo, 1991; 1,725 words), and one was an interview conducted by Liz Carpenter, an old Texas friend, in the general-circulation feminist magazine $M s$ (Carpenter, 1985; 1,868 words).

In Jordan's speech and writing, “The Barbara Jordan style” emerges out of repeated epistemic and interactional stancetaking choices calling attention to personal authority. These choices have to do with a relative lack of interactivity (Jordan does not invite interlocutors to co-construct meaning) and an epistemic stance that projects certainty and identifies herself as the source of knowledge and evaluation. In public oratory as well as 
in face-to-face interview speech, Jordan spoke slowly, in a low, intense voice, articulating clearly and making it apparent that she was choosing words carefully. She projected moral and epistemological authority by drawing attention to her knowledgibility, thoughtfulness, intellect, and adherence to principle.

For example, in our conversational interview with Jordan, we asked her about regional differences in how political campaigns are conducted, and this was her response

(6) Jordan interview

BARBARA JORDAN: Oh, I think uh it's not so much the style of campaigning, the issues are different. The issues of womanizing, to take one current one, are responded to differently, regionally, in my opinion. That you will find in the South more people, and this may be too much of a generalization but I am not sure, more people who place a greater store in marital fidelity than some other regions, now that may or may not be true but I get that sense, and the polls will indicate something like this if you will look at some national Gallup or Harris and how people have responded to the uh machinations the Clinton uh you may find some difference in how that is regarded. So the issues, the political issues I think may play out differently regionally, rather than campaign styles.

Jordan approached the response as a serious task, and calling repeated attention to her thoughtfulness and thought processes, both via explicit markers of 
evidentiality like "I think," "in my opinion," and "I get that sense," and via careful hedging of claims: "this may be too much of a generalization;" "that may or may not be true;" "you may find." Her response is framed in moral rather than behavioral terms: asked to talk about regional differences in style, she talks about regional differences in values

As has also been noted in other cultural settings (Rosaldo 1982, Briggs 1993, Duranti 1994), speakers whose appeal rests on being perceived as moral and intellectual authorities may encourage less overt negotiation of meaning with the audience than speakers whose appeal is more egalitarian. ${ }^{11}$ Jordan constructs an authoritative stance by remaining detached from her audience, frequently making assertions of fact and infrequently attempting to create rapport. She sounds formal, precise, and careful rather than informal or relaxed the way a more audience-centered, rapport-building speaker might.

To operationalize these characteristics of Jordan's stance, I draw on Biber's (1988) work, identifying features in Jordan's talk associated with “informational production" (104-108; 128-135). These are features that clustered, in Biber's study, in official documents, academic prose, biography, press reportage, and other genres characterized by highly integrated, dense, precise representations of information. They include, for example, attributive adjectives, long words, and prepositional phrases, all of which are strategies for condensing information into relatively few words. Spontaneous speeches and interviews typically rank fairly low in the presence of these features; Jordan's 
discourse is exceptional in this regard. Excerpt (2) from our interview, illustrates some of these. As with all our interviewees, we asked Jordan to talk about the sources, as she saw them, of her identity and style. Material that will be discussed below is highlighted.

(7) Jordan interview 
DELMA MCLEOD-PORTER: ... Um, do you view yourself as a Southern speaker, or a Southern person, I mean is your identity sort of in some way tied up with being from the South? I, my own personal experience is that I really like

being from the South, I find it to be uh something that I'm very proud of.

BARBARA JORDAN: Well I uh uh I'm proud of the South too, I wasn't always but uh I grew to become uhh fond of the South and of course it's the race question that uh made the South a negative for me for so long, but when I was a member of Congress, uh the Southerners would y- sort of get together, there was an affinity among the Southern contingent in the United States House of Representatives which you could not count on in any other region of the country, and that was it, it was, there is even, I think there is a Southern Caucus, there was not a Southern Caucus when I was in Congress, but I think, I think there is one now. When when I was there, uh Texas was was sort of a a thing apart and we, at least we considered ourselves a thing apart ((laughing)) and just a little bit superior, eh to tell the truth of the matter. And that's a function of Texas braggadocio, that's what that is.

DM-P: ((laughs))

JUDITH MATTSON BEAN: I was going to ask you how you thought, is Texas really Southern or is it outside of the South, just where does it stand? [[Jordan overlaps Bean several times with "no, that's" and "no"]] JORDAN: Lyndon Johnson said we are Southwest, and that, that's a, that's good enough for me. 
MCLEOD-PORTER: Me too. I'll, I'll buy that. Um Barbara [[Johnstone]]

alluded to something earlier too that I'm curious about, and I noticed that -- I've, coached debate when I was at Kasimir [[High School]] too and I had a lot of wonderful orators, [we went] all over the state $=$

JORDAN: $\quad[\mathrm{Um}-\mathrm{hm}$,$] \quad =good.$

MCLEOD-PORTER: Um [[1.5 sec.]] do you think that um maybe -- this isn't uh n- not very uh articulated very clearly -- do you think that black speakers are more conscious of uh maybe the the value of performative language?

JORDAN: The uh what [[1.0]] black or- oratory is an important ingredient of the black experience because preachers have been so paramount in leadership roles in the black community throughout the country. You are going to find that there are any number of people who are public speakers who try to reflect what they have heard from their minister, and the black minister has a definable and totally uh in my opinion different style of oratory than anybody else in the country. And it is because of that role of the black minister, a role which I don't believe is paramount in any other race or group of people, but it is that, it is there, it is there for us and it is because of that preaching that uh influences I think the way that a person who is black would deliver an an address or a speech. 
A number of features of Jordan's style can be associated with density of information and care in encoding, which characterize relatively informational discourse. Elevated lexical choices, drawn from a writerly register, project care in encoding: a negative, an affinity, the Southern contingent, braggadocio, and adjectives like definable and paramount. Like much Latinate vocabulary, these words tend to be multisyllabic. Care in encoding is also projected through hypotactic, highly embedded syntax, often involving relative clauses: "people who are public speakers who try to reflect what they have heard from their minister" (1. 34-35), "a person who is black" (1. 40). This hypotactic style can be seen clearly in the final sentence; brackets indicate the embeddings here:

(8) Jordan interview, extract 7, lines 37-41

And it is [because of that role of the black minister, a role [[which I don't believe is paramount in any other race or group of people]] but it is that, it is there, it is there for us] and it is [because of that preaching [[that uh influences [[[I think]]] the way [[that a person [[[who is black]]] would deliver an an address or a speech]] ].

Jordan also calls attention to care in encoding via reformulations, stating a claim once in a relatively casual register then restating it in a much more formal way. An example from extract (7) is "the Southerners would y- sort of get together, there was an affinity among the Southern contingent in the United States House of Representatives." Onto the first formulation, "the Southerners would y- sort of get together" is overlaid (Grimes 
1972) a legal-sounding second formulation: "There was an affinity among the Southern contingent in the United States House of Representatives." For the politicians, "the Southern contingent" replaces "the Southerners" with a more specific designation; the speakerly "would sort of get together" is replaced by the more compressed and more informative "affinity among," and the locus, unnamed in the first formulation, is designated in the second by its full legal title, "the United States House of Representatives."

A second pattern of overlay in Jordan's talk does the opposite, shifting from a relatively dense, carefully encoded formulation to a less formal one. In both edited and unedited modes, Jordan's uses of demonstrative pronouns (these, that, and so on) are striking. Like other deictic elements, demonstrative pronouns are often said to characterize talk whose interpretation requires immediate context, like face-to-face conversation, rather than more context-free, non-involved talk. Particularly notable are the demonstrative pronouns in short style-shifted codas Jordan appends again and again to long, carefully worded sentences. There are two examples in excerpt (7) above, one in line 16, "that's what that is," and one in lines 21-22, "that's good enough for me." Excerpts (9) and (10) are from Jordan's 1976 Democratic convention speech:

\section{(9) 1976 Democratic National Convention Keynote Address}

JORDAN: We believe that the people are the source of all governmental power; that the authority of the people is to be extended, not restricted. This can be accomplished only by providing each citizen with every 
opportunity to participate in the management of the government. They must have that.

(10) 1976 Democratic National Convention Keynote Address

JORDAN: We have a positive vision of the future founded on the belief that the gap between the promise and reality of America can one day be finally closed.

\section{We believe that.}

Like the call-and-response patterns they bring to mind, the overlays in these examples project moral certainty; it is as if a second, responsive voice supplements the carefully encoded first formulation with a spontaneous assertion of its truth.

Jordan often uses be as a main verb. Since, in general, be is often used in situations in which there would be a more informative alternative, this may appear inconsistent with the projection of informativity. However, Jordan's main-verb use of be has to do with another fact about this verb: copular be is useful in stating universal, eternal truths. Excerpt (11) provides several examples in a paragraph from the Angelo interview:

(11) Time magazine interview

JORDAN: It is not right; it is not correct; it should not occur. These things may not be illegal, but it is so important for a public servant to sort out what is legal from what is ethical. I tell appointees, "You must not engage in any fine-line drawing." Ed Meese as Attorney General did 


\section{that many times. It is not enough for the Attorney General to say, "I}

\section{have not violated the law."}

Here, even more overtly than in previous extracts, Jordan presents herself as the moral authority, providing no other justification for her claims than her beliefs: "It is not right; it should not occur."

The displays of certainty that permeate Jordan's epistemic stance-taking ground her stance in personal principle and experience. She accomplishes this via stance-taking strategies that point to her cognitive and emotional states. In relatively edited as well as

relatively spontaneous discourse, Jordan also expresses epistemic certainty via verbs and adverbials such as know and of course, predictive modals such as will and would, and “private verbs" (Biber 1988: 105) such as believe and feel, with first-person subjects. The interview excerpt in (2) above includes several examples: I think (twice), I get the sense, and three uses of will. Even though she is making a display of hedged uncertainty here, saying "this may be too much of a generalization" and "that may or may not be true," it is apparent that the authority comes from her own knowledge and moral principle.

Jordan's tendency to base claims on her own authority is also clear in this excerpt from the Time magazine interview. Asked "But don't most people think, cynically, that politics is a crooked business?" Jordan answered: 


\section{(12) Time magazine interview}

JORDAN: I am very disheartened by the public perception of politicians not having the public welfare at heart because I absolutely believe politics is an honorable profession. I wish more people would see politicians as public servants, because that's what they are.

Asked, implicitly, to defend politicians, Jordan refers not to statistics, anecdote, or logical or quasilogical proof, but to her own moral and epistemic certainty: "I absolutely believe politics is an honorable profession"; "[Public servants] is what [politicians] are."

In addition to adducing to her own belief and certainty, Jordan sometimes called attention to the personal history that she claims gave rise to this authoritative stance, linking authoritativeness directly with personal experience. Her two best-known public speeches both begin this way. In both, Jordan begins by adducing the racist history of the U.S., not in the abstract but as connected to her own personal history.

1972 Speech in US House Judiciary Committee, first paragraph

"We the people" -- it is a very eloquent beginning. But when the Constitution of the United States was completed on the $17^{\text {th }}$ of September in 1787 , I was not included in that "We, the people." I felt for many years that somehow George Washington and Alexander Hamilton just left me out by mistake. But through the process of amendments, interpretation and court decision, I have finally been included in "We, the people." 
Jordan's framing of her discussion of the U.S. Constitution in first-person terms is especially striking given the historical context. Since Jordan was not alive in 1787, the $I$ in "I was not included" must be read as a synechdocal reference to African Americans. The same is true of the $I$ in "I have finally been included in 'We, the people," since, although enforcement of their civil rights has always been inconsistent, African Americans became U.S. citizens long before Jordan's birth.

Jordan similarly framed U.S. history as a history of personal exclusion in her 1976 keynote address to the Democratic National Convention. Here, the evidentiary link between this personal history and Jordan's epistemic authority is made explicit: “...my presence here is one additional bit of evidence that the American Dream need not forever be deferred."

\section{(14) 1976 Democratic National Convention Keynote Address, beginning}

One hundred and forty-four years ago, members of the Democratic party first met in convention to select a presidential candidate. Since that time, Democrats have continued to convene once every four years and draft a party platform and nominate a presidential candidate. And our meeting this week is a continuation of that tradition. 
But there is something different about tonight. There is something special about tonight. What is different? What is special? I, Barbara Jordan, am a keynote speaker.

\section{A lot of years have passed since 1832, and during that time it would have been most unusual for any national political party to ask that a Barbara Jordan deliver a keynote address ... but tonight here I am. And I feel that notwithstanding the past that my presence here is one additional bit of evidence that the American Dream need not forever be deferred.}

Rather than saying, as she could have, that during most of the time since 1832 it would have been unusual for "an African American" to be invited to speak to a political party, she says “a Barbara Jordan," linguistically appropriating African American experience as her own; instead of "tonight, here is an African American" she says "tonight here I am." The experience of personal exclusion and subsequent inclusion leads into a characteristic use of a private verb with a first-person subject: "I feel."

A third example can be found in this excerpt from Jordan's keynote address to the 1992 Democratic National Convention. Speaking of the "trickle-down" economics associated with Ronald Reagan and his Vice-President George Bush, the then current Republican presidential candidate, Jordan made reference to her own upbringing in the Fifth Ward in Houston, where she attended public schools: 
(15) 1976 Democratic National Convention Keynote Address, beginning of fourth paragraph

I certainly do not mean the thinly disguised racism and elitism of some kind of trickle-down economics. I mean an economy where a young black woman or man from the Fifth Ward in Houston or South-Central Los Angeles, or a young person in the colonias of the lower Rio Grande Valley can attend public schools and learn the skills that will enable her or him to prosper. We must have an economy that does not force the migrant worker's child to miss school in order to earn less than the minimum wage just so the family can have one meal a day.

Into a list of references to hypothetical youths from inner-city Los Angeles or the industrial slums along the Mexican border, Jordan inserts references to her own history that would have been unmistakeable to many listeners in 1992. She explicitly links this personalized account with an epistemic claim: "We must have an economy that ..." Jordan's own life experience is proffered as the source of her moral certainty.

Consistency across discourse genres is another way in which Jordan enacted an ethos of self. ${ }^{12}$ That she made relatively little concession to circumstance in linguistic style, as also in dress and carriage and in the political positions she publicly espoused, was taken as a sign of moral constancy. She was aware of this and claimed repeatedly in our interview with not to accommodate her speech to the styles or expectations of audiences. 
DELMA MCLEOD-PORTER: Well whenever you're preparing a speech and you know that you're speaking to an audience predominantly of men as opposed to an audience predominantly of women, do you make adjustments to meet the needs of that particular, those particular groups?

JORDAN: ((laughing)) I don't. I really don't.

She then talked about a recent address to a group of women, claiming to make minimal adjustments: “...after I do the rest of the stuff that I want to say here I better throw in ... a good quote that may be appropriate for the occasion, that sort of thing." McLeodPorter probed again:

(17) Jordan interview

MCLEOD-PORTER: Interesting. Um, so then you're not conscious of any kinds of adaptations that speakers make when they're addressing different [audiences] JORDAN:

[I'm not.] I am not.

Jordan did not, in fact, write out even her most formal speeches, relying instead on minimal notes. This is evidence of the value she placed on extemporaneous oral articulateness, an attitude linked to the preaching tradition of the Baptist church, to her high school and college debate training, and to her training as a lawyer. She claimed to value not just the ability to think of something to say in any situation, but the ability to think of the one right thing to say and to phrase it accurately and precisely. By choosing 
to speak extemporaneously rather than read from a script, and by choosing to speak on pre-planned occasions the same way she did on unplanned ones, Jordan projected authoritative thoughtfulness. Thus her choice of medium (speaking rather than writing) is connected, just as her more micro-level choices are, to the ethos of self.

To summarize, the personal epistemic and moral authoritativeness that reflects and constructs the ethos of self is enacted Jordan's discourse in several ways, on several levels: via sentence-level features associated with precision, care, informativity, and certainty, via consistency in their deployment across discourse practices and speech situations, via explicit references to personal experience and its connection to knowledge and belief, and via even more global choices about what sorts of things to do with language and in what media to do this text-building.

\section{Some Evidence from Reception}

Audiences noticed Jordan's consistent, authoritative style, and commented on it, often linking it with personal identity. Biographies of Jordan invariably mention her "characteristic oratorical style and delivery" (Crawford and Ragsdale 1992: 322), sometimes explicitly calling it the "Barbara Jordan style." Commentators alude indirectly to its authoritativeness in several ways. Often noted is the "power" of Jordan's oratory. In a more direct allusion to Jordan's projection of personal authority, political humorist Molly Ivins commented repeatedly that Jordan "sounded like the Lord God Almighty" (Ivins 1996a:17, see also Ivins 1993). Commentators also frequently speak of Jordan's "dignity" and "confidence." In a New York Times Magazine essay after 
Jordan's death in 1996, Ivins said that “[Jordan's] personal dignity was so substantial even admirers hesitated to approach her" (Ivins 1996a: 17); elsewhere, Ivins spoke of Jordan's “strikingly magisterial" presence (Ivins 1996b). The editorial obituary for Jordan in the New York Times spoke explicitly of how her style drew on her personal history: "Combining remarkable oratorical skills with the powerful symbolism of her own personal story, she strove always to rally Americans around the ideals expressed in the Constitution" (New York Times 1996).

\section{DISCUSSION}

To summarize, this paper has built on recent research about how repeated stancetaking moves can come together as a repeatable, locally noticeable style by exploring a case in which a style of stance comes to index not a social identity but a personal identity, a particular lingual biography. I showed how this style was shaped by multiple influences in this woman's sociolinguistic environment, associated with circulating language ideologies but each mediated through the influence of particular people and situations in her life history. In particular, I showed how Barbara Jordan's style of stance instantiated an idea about individuals and discourse that, if currently unpopular among academics, still powerfully shapes some American political discourse. I referred to the rhetorical enactment of this idea as the "ethos of self," and defined it as the strategic discursive display of consistent personal identity, rooted in a speaker's unique personal biography, as contrasted with the flexible "ethos of person" which makes strategic use of flexibility of social identity. 
Sociolinguistics has its roots in a social-scientific tradition of scholarship which has until recently valued generalizations about social actors over generalizations about interactional processes, encouraging research that generalizes over multiple individuals so as to make descriptive or predictive claims about (necessarily idealized) groups. This is changing: even those who value quantitative evidence the most now see the need to explore, in particular instances, the discursive practices and processes that give rise to the patterns they find. However, we continue to pay more attention to social identities and situational registers than to individual social actors. We are more interested in what it takes and what it means to sound African American, to sound female, or to sound like a politician than what it requires to sound like Barbara Jordan and what sorts of interactional work sounding like Barbara Jordan can do; we are skeptical of the possibility that sounding like Barbara Jordan could even be repeatable across genres and interlocutors.

This skepticism about the individual has gone along with the important post-modernist turn to cultural and linguistic relativity which has led to well-founded mistrust of conventional Western ideas about language and identity. Sociolinguists have turned new attention to modeling the behavior of people whose marginality and mobility requires social flexibility not always required of people in the dominant mainstream, and this has given rise to some powerful new ways of imagining language, society, and identity. But if ideology shaped linguistic theory in the past, it does so no less in the present, and it is as important as ever not just to celebrate what can is newly visible through the lens of the moment but also to wonder what observations are rendered more difficult. One of these 
is the observation that, sometimes, linguistic styles may be semiotically associated not with social identities but with individuals.

\section{NOTES}

1. In his analysis of personal experience narrative (Labov and Waletzky 1997[1967], Labov 1972), William Labov uses the term "evaluation" for the features of a narrative whose function is to underscore the extraordinary quality of the represented events and hence the conversational value of the telling. The "evaluative" features Hunston and Thompson describe can all serve Labov's more specific "evaluative" function, since narrative evaluation is a matter of stancetaking.

2. Agha (2003) uses the term "register" in a broader way, to refer to any way of speaking that comes to seem fixed and associated with stable social meaning through ideological/discursive processes of "enregisterment." For Biber and Finegan, situational "registers" and regional/social "dialects" or "varieties" are taxonomically distinct.

3. My primary sources on Jordan's biography are Jordan and Hearon 1979, Crawford and Ragsdale 1992: 321-331, and Rogers 1998; see also Bryant 1977, Haskins 1977. I have also made use of the Barbara Jordan archive at Texas Southern University in Houston, TX. A useful source is the online Biographical Directory of the United States Congress: http://bioguide.congress.gov/scripts/bibdisplay.pl?index=J000266. 
4. The discussion that follows represents Platonic and Aristotelian ethos as they haven conventionally been understood. An overview like this runs the risk of "propounding the reductive and tired disjunction between Plato and Aristotle, and dividing subsequent rhetorical traditions derived from each of them" (Swearingen 1994:116). A longer exposition of the idea of ethos in scholarly discourse in rhetorical studies would be considerably more nuanced. Debate continues about what ethos meant to classical rhetoricians, and there is ongoing discussion about how the concept can be applied across the range of discursive practices with which rhetoricians concern themselves today (Baumlin and Baumlin 1994). Postmodernist rhetorical theorists draw on the Aristotelian conception of ethos, but point to the ways in which the "character" projected into discourse is determined by social positioning and language rather than a matter of free choice.

5. Robin Shoaps (personal communication) points out a similar dualism in anthropological classification systems for conceptualizations of personhood across cultures, oppositions such as "egocentric" versus "sociocentric," or "individualistic" versus "relational." (See, for example, Mauss 1985[1938].) This convergence may have to do with the fact that Western social theory has its roots in the same Western intellectual tradition that gives rise to rhetoric.

6. This is particularly true of the study of cultural and/or temporal "others." As Anthony Cohen points out (1994:5), Western social scientsts have tended not to extend "to cultural 'others' the self consciousness we so value in ourselves." 
7. Like other public American women in a larger study of self-reports about identity (Johnstone 1995), Jordan acknowledges gendered social expectations and gender discrimination but denies that they applied to her.

8. Jordan's lifelong companion was a woman, and it has been claimed that she was a lesbian (see, for example, http://lesbianlife.about.com/cs/woc/p/barbarajordan.htm and http://www.planetout.com/news/history/archive/11081999.html). Lesbianism was not an identity Jordan ever claimed publicly (if she self-identified as a lesbian, she never came out about it), and it was probably not an identity from which Jordan consciously drew stylistic resources in public life. Nonetheless, some members of her audiences may have heard elements of her style as indices of a lesbian identity .

9. The transcription represents all the words spoken that could be identified and located. (Unidentifiable words are in empty parentheses.) I also represent audible paralinguistic material like ((laughter)) as well as [simultaneous talk]

[in aligned square brackets] and latching (with $=$ ). Double square brackets enclose [[editorial clarification]]. Otherwise, readability is a higher priority than realism.

10. Thomas F. Freeman, Distinguished Professor of Forensics at Texas Southern University, jointed the faculty in 1949 and founded its debate team that year. The team has had many successes; a month after our conversation with Jordan, the TSU team won 
the International Forensic Association tournament in London to great acclaim in the Houston press. Among Freeman's former students are many leaders in the Texas and national African American communities.

11. Since, as DuBois (forthcoming) points out, stancetaking involves the mutual orientation of two (or more) social actors, it is always interactive: speakers position themselves, with respect to attitude or afflilation, relative to other speakers. The interactivity of stancetaking is particularly evident in conversational data, where the ways in which interlocutors' uptake shapes each other's contributions are often obvious. But while interactivity in this sense is a sine qua non of any discourse - intersubjectivity is always being negotiated - the degree to which speakers shape each other's utterances in real time varies. Some genres are more interactive than others, and some conversations are more interactive than others. The is the level of "interactivity" I am intersted in here.

12. See Johnstone 1996: 135-156 for an analysis of the cross-genre consistency of Jordan's style compared to that of another African American woman. 


\section{REFERENCES}

Abrahams, Roger D.

1972 The training of the man of words in talking sweet. Language in Society 1:15-29.

Agha, Asif

2003 The social life of a cultural value. Language \& Communication 23:231273.

Angelo, Bonnie

1991, June 3 An ethical guru monitors morality. In Time. Pp. 9-10.

Bauman, Richard

2004 The ethnography of genre in a Mexican market: Form, function, variation. In Style and sociolinguistic variation. P. Eckert and J.R. Rickford, eds. Pp. 57-77. Cambridge: Cambridge University Press.

Baumlin, James $\mathrm{S}$.

1994 Introduction: Positioning ethos in historical and contemporary theory. In Ethos: new essays in rhetorical and critical theory. J.S. Baumlin and T.F. Baumlin, eds. Pp. xi-xxvii. Dallas, TX: Southern Methodist University Press.

Baumlin, James S., and Tita French Baumlin, eds. 1994 Ethos: New essays in rhetorical and critical theory. Dallas, TX: Southern Methodist University Press.

Bellah, Robert N., et al.

1985 Habits of the heart: individualism and commitment in American life.

Berkeley: University of California Press.

Biber, Douglas

1988 Variation across speech and writing. Cambridge: Cambridge University Press.

Biber, Douglas, and Edward Finegan

1989 Styles of stance in English: lexical and grammatical marking of evidentiality and affect. Text 9:93-124.

1994 An analytical framework for register studies. In Dimensions of register variation. D. Biber and E. Finegan, eds. Pp. 31-56. Cambridge: Cambridge University Press.

Braden, Waldo W.

1977 Representative American speeches 1976-1977. New York: H. W. Wilson Company.

Briggs, Charles

1993 Generic versus Metapragmatic dimensions of Warao narratives: Who regiments performance. In Reflexive language. J.A. Lucy, ed. Pp. 179-212.

Cambridge: Cambridge University Press.

Bryant, Ira Babington

1977 Barbara Charline Jordan: From the ghetto to the capital.

Cameron, Deborah

1995 Verbal hygiene. London/New York: Routledge.

Carpenter, Liz 
1985, April On my mind: Barbara Jordan talks about ethics, optimism, and hard choices in government. In Ms. Pp. 75-76; 112.

Cherry, Roger D.

1998 Ethos versus persona: Self-representation in written discourse. Written Composition 15:384-410.

Cohen, Anthony P.

1994 Self consciousness: an alternative anthropology of identity. London:

Routledge.

Crawford, Ann Fears, and Crystal Sasse Ragsdale

1992 Women in Texas: Their lives; their experiences; their accomplishments. 2nd ed. Austin: State House Press.

DuBois, John

forthcoming. In Stancetaking in interaction. R. Englebretson, ed. Amsterdam: John Benjamins.

Duranti, Alessandro

1994 From grammar to politics: linguistic anthropology in a Western Samoan village. Berkeley: University of California Press.

Eckert, Penelope

1989 Jocks and burnouts: social categories and identity in high school. New York and London: Teachers College Press.

2000 Linguistic variation as social practice. Oxford: Blackwell.

Fernea, Elizabeth W., and Marilyn P. Duncan

1977 Texas women in politics. Austin, TX.

Finegan, Edward, and Douglas Biber

2001 Register variation and social dialect variation: The Register Axiom. In

Style and sociolinguistic variation. P. Eckert and J.R. Rickford, eds. Pp. 235-267.

Cambridge: Cambridge University Press.

Goffman, Erving

1959 The presentation of self in everyday life. Garden City, NY: Doubleday

Anchor Books.

1981 Footing. In Forms of talk. Pp. 124-159. Philadelphia: University of Pennsylvania Press.

Greenblatt, Stephen Jay

1980 Renaissance self-fashioning: From More to Shakespeare. Chicago:

Univeristy of Chicago Press.

Grimes, Joseph E.

1972 Outlines and overlays. Language 48:513-524.

Hansen, Olaf

1990 Aesthetic individualism and practical intellect: American allegory in Emerson, Thoreau, Adams, and James. Princeton: Princeton University Press.

Haskins, James

1977 Barbara Jordan. New York: Dial.

Hunston, Susan, and Geoff Thompson, eds. 
2000 Evaluation in text: authorial stance and the construction of discourse. New York: Oxford University Press.

Irvine, Judith T.

2001 "Style" as distinctiveness: The culture and ideology of linguistic differentiation. In Style and sociolinguistic variation. P. Eckert and J.R. Rickford, eds. Pp. 21-43. Cambridge: Cambridge University Press.

Ivins, Molly

1993, August 25 If the Lord comes callin', ask for some ID. In BryanCollege Station Eagle. Pp. A6. Bryan-College Station, TX.

-- $\quad$ 1996a, December 29 She sounded like God. In New York Times Magazine. Pp. 17.

1996b, January 19 Creating justice in law. In Bryan-College Station Eagle. Pp. A11. Bryan-College Station, TX.

Johnstone, Barbara

1995 Sociolinguistic resources, individual identities and the public speech styles of Texas women. Journal of Linguistic Anthropology 5:1-20.

1996 The linguistic individual: Self-expression in language and linguistics. New York: Oxford University Press.

2000 The individual voice in language. Annual Review of Anthropology 29:405-424.

Johnstone, Barbara, and Dan Baumgardt 2004 "Pittsburghese" online: vernacular norming in conversation. American speech 79:115-145.

Jordan, Barbara, and Shirley Hearon

1979 Barbara Jordan: A self-portrait. New York: Doubleday.

Kiesling, Scott F. 2004 Dude. American speech 79:281-305.

Kiesling, Scott F. 2005 Variation, stance, and style: Word-final -er, high rising tone, and ethnicity in Australian English. English World Wide 26:1-44.

Labov, William 1972 The transformation of experience in narrative syntax. In Language in the inner city. Pp. 35-396. Philadelphia: University of Pennsylvania Press.

Labov, William, and Joshua Waletzky 1997 Narrative analysis: Oral versions of personal experience. In Journal of Narrative and Life History, Special issue on Oral Versions of Personal Experience: three decades of narrative analysis. G.E. Michael G. W. Bamberg, ed. Pp. 3-38, Vol. 7.

Lippi-Green, Rosina

1997 English with an accent: Language, ideology and discrimination in the United States. London and New York: Routledge. 
Mauss, Marcel

1985 A category of the human mind: the notion of person, the notion of self. In The category of the person: anthropology, philosophy, history. M. Carrithers, S. Collins, and S. Lukes, eds. Pp. 1-25. Cambridge, UK: Cambridge University Press.

Milroy, James, and Lesley Milroy

1985 Authority in language: investigating language prescription and standardization. London and New York: Routledge and Kegan Paul.

Murchland, Bernard

1987 Voices in America: Bicentennial conversations. Ann Arbor, MI: Prakken Publications.

New York Times

1996, January 19 Barbara Jordan's ideals. In New York Times. New York.

Ochs, Elinor

1992 Indexing gender. In Rethinking context: Language as an interactive phenomenon. A. Duranti and C. Goodwin, eds. Pp. 335-358. New York:

Cambridge University Press.

Pitts, Walter

1989 West African poetics in the Black preaching style. American Speech 64:137-149.

Rogers, Mary Beth

1998 Barbara Jordan: American hero. New York: Bantam Books.

Rosaldo, Michelle Z.

1982 The way we do things with words: Ilongot speech acts and speech act theory in philosophy. Language in society 11:203-237.

1984 Toward an anthropology of self and feeling. In Culture theory: Essays on mind, self, and emotion. R.A. Shweder and R.A. LeVine, eds. Pp. 137-157: Cambridge University Press.

Speicher, Barbara L., and Seane M. McMahon 1992 Some African-American perspectives on Black English Vernacular. Language in Society 21:383-407.

Swearingen, C. Jan 1994 Ethos: imitation, impersonation, and voice. In Ethos: new essays in rhetorical and critical theory. J. S. Baumlin and T.F. Baumlin, eds. Pp. 115-148. Dallas, TX: Southern Methodist University Press.

Tannen, Deborah

1979 What's in a frame? Surface evidence for underlying expectations. In New directions in discourse processing. R. Freedle, ed. Pp. 137-181. Norwood, NJ: Ablex.

- , ed.

1993 Framing in discourse. New York: Oxford University Press.

Wharry, Cheryl

2003 Amen and Hallelujah preaching: Discourse functions in African American Sermons. Language in Society 32:203-225. 
Johnstone, Stance, Style and the Linguistic Individual, 44 